\title{
De kwaliteit van halfjaarrekeningen na implementatie Transparantierichtlijn
}

\section{Een vergelijking tussen Nederlandse en buitenlandse ondernemingen}

Wietse Koster en Rik Opentij

\begin{abstract}
SAMENVATTING Als gevolg van de in 2009 ingevoerde Transparantierichtlijn dienen beursgenoteerde Nederlandse ondernemingen een halfjaarrekening conform IAS 34 op te stellen. De Autoriteit Financiële Markten (AFM) houdt toezicht op de naleving van de voorschriften aangaande de halfjaarlijkse financiële verslaggeving. In dat kader heeft de AFM een onderzoek uitgevoerd naar de kwaliteit van de Nederlandse halfjaarrekeningen. Wij hebben een onderzoek gedaan onder Europese ondernemingen op dezelfde punten als de AFM heeft onderzocht en waarover zij heeft gepubliceerd. Aan de hand van deze onderzoeken vergelijken wij de kwaliteit van de halfjaarrekeningen in binnen- en buitenland. Uit het onderzoek blijkt dat de compliance van de onderzochte buitenlandse halfjaarrekeningen in het algemeen beter is. Daarbij is opvallend dat de betrokkenheid van de accountant bij de halfjaarrekening in het buitenland veel groter is.
\end{abstract}

\section{RELEVANTIE VOOR DE PRAKTIJK Het opstellen van halfjaarrekeningen conform IAS} 34 is in Nederland een nieuwe verplichting. Uit ons onderzoek blijkt dat er in Nederland nog een kwaliteitsslag is te maken in vergelijking met het buitenland. Dit artikel geeft inzicht in de onderdelen van de halfjaarrekeningen waarvoor dit met name geldt en geeft een aantal best practices.

\begin{abstract}
1 Inleiding
Nederlandse beursgenoteerde ondernemingen zijn vanaf 1 januari 2009 wettelijk verplicht om halfjaarlijkse financiële verslaggeving te publiceren. De halfjaarrekening van ondernemingen die verplicht zijn een geconsolideerde jaarrekening op te maken, dient te voldoen aan de IFRSbepalingen. Deze wijziging is het gevolg van het implementeren van de Europese Transparantierichtlijn ${ }^{1}$ in de Nederlandse wetgeving.
\end{abstract}

De Transparantierichtlijn is in Nederland relatief laat ingevoerd. Op grond van de richtlijn zelf had deze uiterlijk
20 januari 2007 in de nationale regelgeving dienen te zijn opgenomen. Nederland heeft de daarvoor benodigde wetswijziging in de tweede helft van 2008 doorgevoerd. Als gevolg van latere invoering van de regelgeving heeft de verplichte publicatie van halfjaarlijkse financiële verslaggeving in Nederland later plaatsgevonden dan in de rest van de EU (EU Commission Staff, 2010). Hetzelfde geldt ook voor Hongarije, Polen en Tsjechië. Uit onderzoek van de AFM blijkt dat voor invoering van de nieuwe regelgeving $25 \%$ helemaal geen halfjaarrekening uitbracht en dat van de uitgebrachte halfjaarrekeningen 50\% aan IAS 34 voldeed, per saldo is dat $38 \%$ van de ondernemingen. Dat komt vrijwel overeen met een onderzoek van KPMG (2009) dat op een percentage van $40 \%$ uitkomt.

Met ingang van 2009 houdt de AFM ook toezicht op de naleving van de voorschriften aangaande de halfjaarlijkse financiële verslaggeving.

De kwaliteit van de Nederlandse halfjaarlijkse verslaggeving in 2009 is in een aantal onderzoeken onder de loep genomen. In mei 2010 publiceerde de AFM (2010) de resultaten van een door haar gehouden themaonderzoek naar de kwaliteit van de Nederlandse halfjaarlijkse financiële verslaggeving 2009. Dit rapport schetst een beeld van de kwaliteit van de Nederlandse halfjaarlijkse financiële verslaggeving. In dit artikel steunen wij op de uitkomsten van dit onderzoek naar de Nederlandse halfjaarrekening en zetten de uitkomsten daarvan uiteen. Daarnaast gebruiken wij resultaten uit een eveneens in mei 2010 gepubliceerd onderzoek naar de halfjaarrekening 2009 van Litjens (2010). Dat doen wij wanneer dit onderzoek aanvullende inzichten biedt bij de bevindingen van de AFM.

In aanvulling op deze onderzoeken hebben wij de kwaliteit van de halfjaarrekening buiten Nederland onderzocht en hebben daarbij aansluiting gezocht bij de door de AFM 
onderzochte onderwerpen. Wij zullen de resultaten van dat onderzoek afzetten tegen de kwaliteit van de halfjaarrekening in Nederland, zoals deze uit genoemde onderzoeken blijkt, om te zien in hoeverre daar verschillen tussen zitten en om best practices te identificeren.

In paragraaf 2 van dit artikel starten wij met een beknopte uiteenzetting over de inhoud van de halfjaarlijkse financiële verslaggeving en in paragraaf 3 gaan wij in op de uitgangspunten van IAS 34. Vervolgens behandelen wij in paragraaf 4 de onderzoeken naar de Nederlandse en buitenlandse halfjaarrekeningen. Dit doen we door voor een aantal IAS 34-vereisten de naleving te behandelen, waarbij wij een aantal best practices opnemen. Wij eindigen dit artikel met een aantal conclusies in paragraaf 5 .

\section{Halfjaarlijkse financiële verslaggeving}

De Nederlandse wetgever heeft de Transparantierichtlijn in de Wet op het Financieel Toezicht (Wft) opgenomen. Eén van de gevolgen van de invoering van de Transparantierichtlijn is dat beursgenoteerde ondernemingen vanaf 1 januari 2009 wettelijk verplicht zijn om halfjaarlijkse financiële verslaggeving te publiceren. Het gaat daarbij om ondernemingen die aandelen of obligaties hebben uitgegeven die genoteerd staan op een gereglementeerde markt. Alternext valt hier bijvoorbeeld niet onder. De bepalingen over de halfjaarlijkse financiële verslaggeving staan in artikel 5:25d van de Wft. Daarin staat voorgeschreven dat de onderneming haar halfjaarlijkse financiële verslaggeving binnen twee maanden na afloop van de halfjaarperiode dient te publiceren. De halfjaarlijkse financiële verslaggeving bestaat uit een halfjaarverslag, een halfjaarrekening en een verklaring van het bestuur betreffende de getrouwheid van de gegevens. De halfjaarrekening dient aan IFRS te voldoen als de beursgenoteerde onderneming verplicht is een geconsolideerde jaarrekening op te maken. Voor alle in dit onderzoek betrokken ondernemingen is dit het geval. Daarbij is vooral IAS 34 van belang, aangezien deze IFRS specifiek ingaat op tussentijdse financiële verslaggeving.

Het halfjaarverslag bevat in ieder geval een opsomming van belangrijke gebeurtenissen in het voorafgaande halfjaar, het effect daarvan op de halfjaarrekening en een beschrijving van de voornaamste risico's en onzekerheden voor de overige zes maanden van het betreffende boekjaar. Tenzij uitsluitend schuldbewijzen aan de beurs zijn genoteerd, moeten ook de belangrijkste transacties met verbonden partijen worden vermeld.

In de verklaring van de ondernemersbestuurders verklaren deze dat de halfjaarlijkse financiële verslaggeving een getrouw beeld geeft. Deze verklaring is vergelijkbaar met die die de bestuurders vanaf 1 januari 2009 bij de reguliere jaarrekening dienen op te nemen.
De halfjaarrekening hoeft niet door de accountant gecontroleerd of beoordeeld te worden. Als er een controle of beoordeling heeft plaatsgevonden, dan wordt de door de accountant afgegeven verklaring bij de halfjaarrekening gevoegd. Indien er geen accountantscontrole of beoordeling heeft plaatsgevonden, dan dient dit feit in het halfjaarverslag te worden vermeld.

In dit artikel richten wij ons op de halfjaarrekening en dan in het bijzonder de vereisten van IAS 34 .

\section{Uitgangspunten van IAS 34}

IAS 34 geeft minimumvereisten voor de inhoud en regels voor de wijze waarop de IFRS dienen te worden toegepast in de halfjaarrekening. Daarbij volgt zij de gedachte dat de gebruiker van de tussentijdse verslaggeving ook kennis zal hebben van de meest recente IFRS-jaarrekening van de onderneming. Om herhaling van informatie te voorkomen, geeft IAS 34 daarom de mogelijkheid om het merendeel van in de reguliere IFRS-jaarrekening opgenomen toelichtingen weg te laten. In plaats daarvan dient het tussentijdse verslag inzicht te verschaffen in relevante gebeurtenissen en wijzigingen ten opzichte van de laatste jaarrekening. Daarbij gaat het om gebeurtenissen en transacties met een significante invloed op de financiële positie en prestaties van de onderneming (IAS 34.15).

IAS 34 bereikt dit door slechts een beperkte hoeveelheid toelichtingen te eisen. Die hoeven alleen te worden opgenomen als het om materiële informatie gaat. Daar bovenop bevat IAS 34 de bepaling dat alle gebeurtenissen en transacties dienen te worden vermeld die van materieel belang zijn voor het inzicht in de tussentijdse periode. In de volgende paragraaf gaan wij nader op de vereiste toelichtingen in.

Naast de bepalingen over de informatieverschaffing bevat IAS 34 aanwijzingen over de wijze waarop de materialiteit wordt bepaald, hoe bepaalde posten worden gewaardeerd en hoe om dient te worden gegaan met eventuele restatements. Vanwege de beperkte relevantie voor dit artikel gaan wij daar verder niet op in.

\section{Toepassing IAS 34}

\subsection{Onderzoeksopzet}

In de eerdergenoemde onderzoeken naar de Nederlandse halfjaarrekening wordt vooral gekeken naar de volgens IAS 34 minimaal op te nemen toelichtingen. Uit de onderzochte kenmerken hebben wij een selectie gemaakt, die bij elkaar een omvattend beeld geeft van de kwaliteit van de halfjaarrekening. Voor de buitenlandse halfjaarrekeningen hebben wij ons gericht op door de AFM in haar onderzoek betrokken onderdelen, om een vergelijking tussen de 
Nederlandse en buitenlandse halfjaarrekeningen te kunnen maken.

De onderzoeken van de AFM en Litjens zijn verricht op de halfjaarrekeningen 2009. Door de AFM zijn 60 halfjaarrekeningen onderzocht en door Litjens 100. De selectie van de AFM bestaat uit 15 ondernemingen met een notering aan de AEX, 15 ondernemingen met een notering aan de AMX, 15 ondernemingen met een notering aan de ASCX en 15 ondernemingen genoteerd in de categorie overige. Voor het overige heeft de AFM geen verdere uitsplitsing gegeven van de onderzochte ondernemingen. Het onderzoek van Litjens betreft 100 beursondernemingen die niet behoren tot de financiële sector.

Wij hebben 60 halfjaarrekeningen 2009 van buitenlandse ondernemingen onderzocht, hetzelfde aantal halfjaarrekeningen dat de AFM in haar onderzoek heeft betrokken. De buitenlandse ondernemingen zijn geselecteerd uit de FTSE Eurotop 100 per 30 april 2010. De geselecteerde buitenlandse ondernemingen zijn gemiddeld groter van omvang dan de door de AFM in haar onderzoek betrokken ondernemingen. Bij de selectie van deze buitenlandse halfjaarrekeningen zijn de in deze index opgenomen Nederlandse ondernemingen, ondernemingen die niet op basis van IFRS rapporteren en halfjaarrekeningen die niet beschikbaar zijn in de Engelse taal buiten beschouwing gelaten. Gezien de doelstelling van de transparantierichtlijn is het daarnaast opvallend dat wij van een aantal ondernemingen er niet in zijn geslaagd om de op basis van IAS 34 opgestelde halfjaarrekening te vinden op de websites van deze ondernemingen.

\subsection{Indeling halfjaarlijkse financiële verslaggeving}

De Wft maakt een duidelijk onderscheid tussen de halfjaarrekening en het halfjaarverslag. Beide kennen minimale inhoudsvereisten. Voor het halfjaarverslag staan die in de Wft en voor de halfjaarrekening blijken die uit IAS 34 . Het onderscheid tussen het halfjaarverslag en de halfjaarrekening blijkt in de praktijk niet altijd duidelijk, zo constateert de AFM. Voor het uitvoeren van het themaonderzoek meldt de AFM daarom dergelijke rapportages op een pragmatisch wijze te hebben ingedeeld naar jaarverslag en jaarrekening. Hoewel het in IAS 1.49 vereiste onderscheid tussen jaarrekening en overige documenten ook op tussentijdse berichtgeving van toepassing is (IAS 34.12), is IAS 34 op dit punt niet geheel consequent. In IAS 34.16, waarin de op te nemen toelichtingen worden uiteengezet, staat dat een toelichting in de halfjaarrekening dient te worden opgenomen als deze 'niet elders in het tussentijds financieel verslag is vermeld'. Uit de tekst van IAS 34.16 volgt dus dat toelichtingen die al in het halfjaarverslag worden gegeven in de halfjaarrekening mogen worden weggelaten. Dit standpunt wordt ook in de literatuur aangetroffen (Bonham et al., 2010, p. 2894).
Vanuit functioneel oogpunt bezien heeft het niet herhalen van in het halfjaarverslag opgenomen informatie, of het samenvoegen van halfjaarverslag en halfjaarrekening, als voordeel dat doublures worden voorkomen. Bepaalde in het halfjaarverslag toegelichte gebeurtenissen en transacties, namelijk die die materieel voor het inzicht in de financiële positie en prestaties zijn, dienen ook op grond van IAS 34 te worden opgenomen. Daar staat echter tegenover dat de halfjaarrekening dan geen zelfstandig bruikbaar stuk is. De gebruiker van de halfjaarrekening zal ook kennis van het halfjaarverslag moeten nemen om verzekerd te zijn van het vereiste inzicht in de halfjaarrekening. Bovendien bevat het halfjaarverslag niet alleen historische maar ook toekomstgerichte informatie. Bij door een accountant beoordeelde of gecontroleerde halfjaarrekeningen is bijkomend praktisch bezwaar dat de in het halfjaarverslag opgenomen informatie aan een beperkte accountantsbeoordeling onderhevig is. Om die redenen vinden wij dat het de voorkeur heeft om het in de Wft gemaakte onderscheid tussen de halfjaarrekening en het halfjaarverslag te volgen en geen toelichtingen uit de halfjaarrekening weg te laten wanneer die informatie in het halfjaarverslag is opgenomen.

Bij de buitenlandse onderzochte halfjaarlijkse financiële verslaggeving wordt dit onderscheid tussen halfjaarverslag en halfjaarrekening in het algemeen gemaakt, met name bij Franse, Engelse en Zwitserse ondernemingen. In sommige landen geldt lokale wetgeving of vereisten van de toezichthouder die hier mede debet aan lijken te zijn, bijvoorbeeld in Frankrijk, waar de halfjaarrekening in de vorm van een registratiedocument wordt opgesteld. Echter ook in het buitenland zien wij rapportages waarbij het onderscheid tussen halfjaarverslag en de halfjaarrekening niet duidelijk is.

\subsection{Primaire overzichten}

IAS 34.8 vereist dat de onderneming alle primaire overzichten uit IAS 1 opneemt. Dit zijn de Statement of financial position, Statement of comprehensive income, Statement of changes in equity en Statement of cash flows. Deze overzichten mogen wel worden verkort door lijnitems samen te voegen. Daarbij gelden als voorwaarden dat alle kopjes en subtotalen bewaard blijven en dat additionele posten of toelichtingen worden opgenomen indien het weglaten ervan de overzichten misleidend zou maken. Bij de primaire overzichten valt op dat Nederlandse ondernemingen niet allemaal het in 2009 ingevoerde overzicht (statement) van comprehensive income hebben opgenomen. Van de door de AFM onderzochte ondernemingen schoten er negen $(15 \%)$ hierin tekort, in de door Litjens onderzochte populatie bedroeg dat aantal zelfs $40 \%$. Verder constateert de AFM dat in zeven gevallen niet alle kopjes en subtotalen in het mutatieoverzicht eigen vermogen waren opge- 
nomen en in drie gevallen vergelijkende cijfers ontbraken. Overigens is opvallend dat $64 \%$ van de door de AFM onderzochte ondernemingen de volledige statements opneemt in plaats van verkorte statements.

Aangezien de onderzochte ondernemingen beursgenoteerd zijn, dienen deze ook de winst per aandeel in de halfjaarrekening op te nemen. Van de door de AFM onderzochte Nederlandse ondernemingen hebben er drie de verwaterde winst per aandeel niet toegelicht. Daarnaast trof de AFM één onderneming aan waarbij de toelichting op de verkeerde plaats was opgenomen.

Van de 60 onderzochte buitenlandse ondernemingen is voor twee ondernemingen de aanpassing in IAS 1 nog niet van toepassing, aangezien dit ondernemingen waren met een halfjaar eindigend per respectievelijk 31 maart en 31 mei 2009. Bij de overige 58 halfjaarrekeningen is in drie halfjaarrekeningen het overzicht van comprehensive income wel opgenomen, maar begint dit overzicht niet met de winst/verlies over de periode, hetgeen op basis van IAS 1.81 (b) vereist is. Opmerkelijk is dat één van deze drie ondernemingen in haar halfjaarrekening 2009 aangeeft dat zij de aanpassing in IAS 1 zal gaan toepassen per 31 december 2009 en dat de effecten van deze aanpassingen nog worden onderzocht. Deze wijze van toepassen van de grondslagen in de halfjaarrekening is niet in overeenstemming met IAS 34.28. Resumerend kan worden gesteld dat 55 van de 58 (95\%) onderzochte buitenlandse halfjaarrekeningen op een juiste manier heeft voldaan aan de nieuwe eisen ten aanzien van de hoofdoverzichten.

Voor wat betreft de (verwaterderde) winst per aandeel hebben wij bij één buitenlandse onderneming vastgesteld dat deze informatie niet in de winst-en-verliesrekening was opgenomen maar in de toelichting.

\subsection{Grondslagen}

De halfjaarrekening hoeft de grondslagen niet te bevatten. In plaats daarvan bepaalt IAS 34.16(a) dat in de halfjaarrekening een verwijzing wordt opgenomen naar de grondslagen in de meest recente jaarrekening. Voor zover er wijzigingen in de grondslagen hebben plaatsgevonden, worden de aard en het effect daarvan toegelicht. De AFM meldt dat alle door haar onderzochte ondernemingen een verwijzing naar de grondslagen in de meest recente jaarrekening hebben opgenomen. Van de door de AFM onderzochte ondernemingen hebben er $42(70 \%)$ ook de wijzigingen ten gevolge van de aanpassing en invoering van nieuwe IFRS-standaarden toegelicht. Theoretisch gezien kan het zo zijn dat de overige 18 (30\%) ondernemingen de verplichte wijzigingen al vervroegd hadden ingevoerd. Maar 2009 was het eerste boekjaar waarin het statement of comprehensive income diende te worden opgenomen. In dat licht bezien vinden wij het percentage van $30 \%$ zo hoog dat wij het aannemelijk achten dat een deel van de $30 \%$ deze toelichting ten onrechte achterwege heeft gelaten. De AFM doet hier verder geen mededelingen over.

Bij de 60 onderzochte buitenlandse halfjaarrekeningen is bij 58 (97\%) ondernemingen een verwijzing aangetroffen naar de grondslagen in de jaarrekening 2008. Verder is bij $54(90 \%)$ ondernemingen een toelichting opgenomen over de wijzigingen als gevolg van nieuw van toepassing zijnde IFRS. Van het niet opnemen van een toelichting op wijzigingen door nieuw van toepassing zijnde IFRS kan niet onmiddellijk worden geconcludeerd dat sprake is van noncompliance. Voor ondernemingen met gebroken boekjaren gelden bepaalde standaarden pas in het volgend boekjaar en er zijn ondernemingen die de nieuwe standaarden (bijvoorbeeld IFRS 8) al vervroegd hadden toegepast.

\subsection{Cyclische en seizoenseffecten}

Op grond van IAS 34.16 (b) neemt de onderneming een toelichting op over het seizoensgebonden of cyclische karakter van tussentijdse bedrijfsactiviteiten. Door de AFM is dit in $17(27 \%)$ van de onderzochte halfjaarrekeningen aangetroffen. Niet onderzocht is welk deel van de ondernemingen daadwerkelijk seizoensgebonden of cyclische bedrijfsactiviteiten heeft. Bij de 60 onderzochte buitenlandse halfjaarrekeningen is bij 21 (35\%) ondernemingen een opmerking opgenomen over het seizoensgebonden of cyclische karakter van de tussentijdse bedrijfsactiviteiten

Deze toelichting kan in drie groepen worden verdeeld:

- een opmerking dat er geen sprake is van seizoenseffecten op de gepresenteerde halfjaarcijfers;

- een tekstuele toelichting waarin wordt ingegaan op de seizoenseffecten, zonder dit verder uit te werken met de gevolgen hiervan voor de gepresenteerde cijfers;

- een tekstuele toelichting waarbij financiële informatie wordt verstrekt over de 12- maandsperiode tot en met het einde van het gepresenteerde halfjaar.

Ondernemingen met zeer seizoensgebonden bedrijfsactiviteiten, worden aangemoedigd (IAS 34.21) om de als derde genoemde toelichting op te nemen. Dergelijke informatie is bij geen van de Nederlandse ondernemingen die in het onderzoek van de AFM zijn meegenomen, aangetroffen. Ook bij de 60 onderzochte buitenlandse ondernemingen wordt deze toelichting niet aangetroffen. Een onderneming die deze toelichting wel opneemt in de halfjaarrekening 2009, en klaarblijkelijk buiten de onderzoekspopulatie van de AFM is gebleven, is Philips (zie figuur 1).

\subsection{Segmentering}

Ondernemingen die conform de bepalingen van IFRS 8 gesegmenteerde informatie in hun jaarrekening opnemen, 
Figuur 1 Philips, Quarterly report \& Semi-annual report 2009, p. 32.

\begin{abstract}
4 Seasonality
The Group's sales are impacted by seasonal fluctuations, particularly driven by Consumer Lifestyle and Healthcare, typically resulting in higher revenues and earnings in the second half-year results. At Consumer Lifestyle, sales and earnings are usually much higher in the second half-year, largely due to higher consumer spending in the second half-year driven by the holiday season. At Healthcare, sales are higher in the second half-year largely due to the timing of new product availability and customers attempting to spend their annual budgeted allowances before the end of the year.

For the 12 months ended June 28, 2009, Healthcare, Consumer Lifestyle and Lighting had revenues of EUR 7,987 million, EUR 9,057 million and EUR 6,838 million respectively (12 months ended June 29, 2008: EUR 6,856 million, EUR 12,931 million and EUR 6,852 million respectively) and reported income from operations of EUR 521 million, a loss of EUR 33 million and a loss of EUR 411 million respectively (12 months ended June 29, 2008: EUR 729 million, EUR 770 million and EUR 706 million respectively).
\end{abstract}

dienen ook bepaalde gesegmenteerde informatie in de halfjaarrekening op te nemen. IAS $34.16(\mathrm{~g})$ beschrijft welke van de in IFRS 8 genoemde informatie minimaal in de halfjaarrekening dient te worden opgenomen. Van de door de AFM onderzochte ondernemingen hebben er vijf een ontoereikende toelichting opgenomen.

In alle onderzochte buitenlandse halfjaarrekeningen is de relevante segmentinformatie op basis van IAS $34.16(\mathrm{~g})$ opgenomen. Hierbij dient wel te worden opgemerkt dat in die gevallen waarbij er geen duidelijk onderscheid is tussen het halfjaarverslag en de halfjaarrekening, deze informatie vaak is opgenomen voorafgaand aan de primaire overzichten. Bij deze ondernemingen blijkt het belang van segmentinformatie wel te worden onderkend, gezien het feit dat deze informatie een relatief groot deel van de halfjaarlijkse financiële verslaggeving inneemt.

\subsection{Mutaties in het ondernemingsvermogen}

De wijzigingen in het eigen en vreemd vermogen dienen volgens IAS 34.16 (e) te worden toegelicht. Uit het onderzoek van Litjens blijkt dat wijzigingen van het aantal uitstaande aandelen en significante wijzigingen in de langlopende leningen in respectievelijk $75 \%$ en $72 \%$ van de gevallen zijn toegelicht.

Over dividend is in IAS 34.16 ( $\mathrm{f}$ ) bepaald dat het bedrag per soort aandeel dient te worden opgenomen. De AFM constateert dat bij 41 van de 43 ondernemingen die dividend uitkeerden het dividend in ieder geval is opgenomen in het mutatieoverzicht van het eigen vermogen. Bij 28 (68\%) ondernemingen worden daar aanvullende toelichtingen op gegeven. Wanneer een onderneming slechts één klasse aandelen kent, kan toelichting in het mutatieoverzicht van het eigen vermogen volstaan om aan de IAS 34-eisen te voldoen.

Bij de buitenlandse halfjaarrekeningen komen we op deze onderdelen tot licht hogere percentages. Additionele informatie (in aanvulling op de gegevens opgenomen in het mutatieoverzicht van het eigen vermogen en het kasstroomoverzicht) over wijzigingen in aandelen en significante wijzigingen in langlopende leningen wordt door $47(78 \%)$ van de onderzochte ondernemingen verstrekt en een additionele toelichting op dividend is in 46 (77\%) van de halfjaarrekeningen opgenomen.

\subsection{Bedrijfscombinaties}

IAS 34.16 (i) verwijst voor de toelichtingen over het verwerven van bedrijfsonderdelen naar de uitgebreide toelichtingsvereisten zoals die zijn opgenomen in IFRS 3 . Bij vijf van de door de AFM onderzochte ondernemingen is er sprake van bedrijfscombinaties. Het rapport van de AFM geeft aan dat in geen enkel geval volledig aan de vereisten van IFRS 3 wordt voldaan. De AFM meldt echter niet welke toelichtingen ontbreken. Om die reden hebben wij de toelichtingen over bedrijfscombinaties in de Nederlandse halfjaarrekeningen 2009 aanvullend onderzocht. Aangezien de onderzoekspopulatie van de AFM niet openbaar is, hebben wij zelf een selectie uit de AEX en AMX gemaakt. Die selectie bestaat uit de Nederlandse vennootschappen die geen financiële instelling zijn, in totaal 39 ondernemingen. In de eerste helft van 2009 hadden van die ondernemingen negen één of meer acquisities gepleegd. Daarvan hebben drie ondernemingen de door IFRS voorgeschreven toelichtingen opgenomen. Van de zes resterende ondernemingen die de toelichtingen niet opnamen, vermelden er vier dat dit is omdat de overnames niet materieel zijn voor de halfjaarrekening en bij de andere twee ontbreekt enige mededeling.

IFRS 3 is in 2008 herzien. De toepassing van de herziene IFRS 3 is verplicht met ingang van boekjaren die aanvangen na 1 juli 2009. Dat betekent dat de meeste ondernemingen in hun halfjaarrekening 2009 nog de oude IFRS 3 -standaard mochten toepassen. De drie ondernemingen die hun overnames toelichten, passen allen de oude IFRS 3 -standaard toe.

De drie halfjaarrekeningen waarin overnames worden toegelicht, bevatten de belangrijkste vereiste toelichtingen. Geen van drieën is echter compleet. Eén van de drie ondernemingen geeft de op grond van IFRS 3.67 (i) en 3.70 vereiste toelichtingen op resultaat en omzet van de overgenomen ondernemingen. Opvallend genoeg nemen alle drie de ondernemingen een halfjaar later deze gegevens wel op in hun volledige jaarrekening over 2009. Een andere 
Figuur 2 Centrica, Condensed interim Financial Statements 2009, p. 50

\begin{tabular}{|c|c|c|}
\hline & Key factors & $\begin{array}{l}\text { Increase/(decrease) in fair } \\
\text { value of net assets of SPE } \\
\text { at acquisition date } \\
\qquad \mathrm{m}\end{array}$ \\
\hline Other intangible assets & $\begin{array}{l}\text { Updated assumptions and estimates within the intangible assets valuation models for customer } \\
\text { relationships and a power purchase agreement. }\end{array}$ & (77) \\
\hline Property, plant and equipment & $\begin{array}{l}\text { Updated assumptions and expectations in respect of key inputs used in the valuation models for power } \\
\text { generation assets. }\end{array}$ & (13) \\
\hline Trade and other receivables & $\begin{array}{l}\text { Updated assumptions and expectations in respect of key inputs used in the valuation models for } \\
\text { in-the-money 'own use' energy procurement contracts. }\end{array}$ & 8 \\
\hline Trade and other payables & $\begin{array}{l}\text { Updated assumptions and expectations in respect of key inputs used in the valuation models for } \\
\text { out-of-the-money 'own use' energy procurement contracts. }\end{array}$ & 96 \\
\hline Derivative financial instruments & $\begin{array}{l}\text { Updated assumptions and expectations in respect of key inputs used in the valuation models for } \\
\text { acquired energy procurement contracts. }\end{array}$ & (45) \\
\hline Net deferred tax liabilities & $\begin{array}{l}\text { Changes in the fair value adjustments, resulting in a change in deferred tax liabilities arising as part of } \\
\text { the business combination. }\end{array}$ & 14 \\
\hline
\end{tabular}

tekortkoming betreft de naleving van IFRS 3.66 (d), die bepaalt dat de samenstelling van de overnamesom dient te worden toegelicht. Bij geen van de ondernemingen troffen wij dit aan. Ten slotte troffen wij geen toelichtingen aan op grond van IFRS 3.67 (e) en IAS 34.47 (b). Dat betreft respectievelijk informatie over na de overname af te stoten operaties en informatie over voorwaardelijke verplichtingen. De afwezigheid van die informatie kan echter ook komen doordat dit bij de betreffende overnames niet relevant is.

IFRS 3.71 vereist verder dat niet alleen overnames in de verslagperiode worden toegelicht, maar ook die uit de periode tussen de balansdatum en de opsteldatum van de jaarrekening. Naar onze mening ligt het voor de hand dat dit ook voor de halfjaarrekening geldt. Slechts bij één onderzochte Nederlandse onderneming was er sprake van een overname na balansdatum, die op het moment van rapporteren al definitief overeengekomen was. Daarnaast hadden drie andere ondernemingen al overeenstemming over een overname bereikt, maar werd nog gewacht op toestemming van de mededingingsautoriteiten. In geen van deze vier gevallen werden de IFRS 3 -toelichtingen gegeven. Uit het feit dat de IFRS 3-toelichtingen over deze overnames een halfjaar later wel in de reguliere jaarrekening 2009 worden gegeven, leiden wij af dat het in alle gevallen om materiële overnames gaat. $\mathrm{Nu}$ stelt IAS 34.16 (i) dat toelichting moet worden gegeven op 'the effect of changes in the composition of the entity during the interim period, including business combi- nations'. Hoewel het waarschijnlijk niet de bedoeling is, is dit op te vatten als vrijstelling voor het opnemen van toelichtingen over bedrijfscombinaties na balansdatum in de interim-rapportage. Mogelijk dat dit een rol speelt bij het ontbreken van toelichtingen over overnames na balansdatum in de halfjaarrekeningen.

In de buitenlandse halfjaarrekeningen wordt door 46 ondernemingen (77\%) melding gemaakt van wijzigingen in de samenstelling van de groep. Dit betreft niet alleen bedrijfscombinaties, maar wijzigingen in de groep in brede zin. Wanneer sprake is van een bedrijfscombinatie wordt steeds aangegeven dat deze niet materieel is of is de toelichting zoals deze op basis van IFRS 3 wordt gevraagd, opgenomen. In slechts één halfjaarrekening hebben wij over een significante bedrijfscombinatie niet de informatie aangetroffen die op basis van IAS 34.16 (i) en IFRS 3 mag worden verwacht. Dat betekent dat in de buitenlandse halfjaarrekeningen ten aanzien van bedrijfscombinaties meer informatie wordt toegelicht dan in de Nederlandse halfjaarrekeningen.

Wij hebben in figuur 2 en 3 een tweetal toelichtingen op bedrijfscombinaties in halfjaarrekeningen opgenomen die relevante informatie bevatten en meer relevante informatie geven dan gebruikelijk lijkt bij Nederlandse ondernemingen.

Centrica Plc heeft op 20 januari 2009 een overname gedaan en heeft deze overname in de halfjaarrekening toegelicht conform IFRS 3. Voorts voegt Centrica een overzicht toe 
Figuur 3 Roche, Half-Year Report 2009, p. 56

\begin{tabular}{|c|c|c|c|c|c|}
\hline \multicolumn{6}{|c|}{ Acquisitions - 2009: impact on results | in millions of CHF } \\
\hline & $\begin{array}{l}\text { Revenues from } \\
\text { external customers }\end{array}$ & $\begin{array}{l}\text { Inventory fair value } \\
\text { adjustment }\end{array}$ & $\begin{array}{l}\text { Amortisation of } \\
\text { intangible assets }\end{array}$ & Operating profit & Net income \\
\hline \multicolumn{6}{|l|}{ Impact on reported results } \\
\hline Memory $^{\mathrm{a}}$ & - & - & - & (8) & (5) \\
\hline Pharmaceutical Division & - & - & - & (8) & (5) \\
\hline Minor business combinations ${ }^{\mathrm{a}}$ & 6 & - & (2) & - & - \\
\hline Diagnostics Division & 6 & - & (2) & - & - \\
\hline Group & 6 & - & (2) & (8) & (5) \\
\hline \multicolumn{6}{|c|}{$\begin{array}{l}\text { Estimated impact on results if acquisition assumed } \\
\text { effective } 1 \text { January } 2009\end{array}$} \\
\hline Memory ${ }^{\mathrm{a}}$ & - & - & - & (8) & (5) \\
\hline Pharmaceuticals Division & - & - & - & (8) & (5) \\
\hline Minor business combinations ${ }^{\mathrm{a}}$ & 12 & - & (4) & 1 & 1 \\
\hline Diagnostics Division & 12 & - & (4) & 1 & 1 \\
\hline Group & 12 & - & (4) & (7) & (4) \\
\hline
\end{tabular}

waarin zij uitlegt welke aanpassingen zijn gemaakt in de reële waarden van de verschillende identificeerbare activa en passiva ten opzichte van de informatie over de initiële inschatting van de reële waarden zoals in de toelichting bij de jaarrekening 2008 op basis van IFRS 3.71 was opgenomen.

IFRS 3.67 (i) vraagt om een toelichting van het resultaat van de gekochte entiteit vanaf de acquisitiedatum. In de praktijk wordt deze toelichting vaak gegeven door middel van een stukje tekst onder de tabel met de reële waarden van de gekochte activa en passiva. Roche Holding Ltd geeft daarentegen een uitgebreid overzicht van de effecten per overname op het resultaat en laat de impact op vijf componenten van het resultaat en per divisie zien, waardoor het effect van de acquisities beter zichtbaar is gemaakt.

\subsection{Verbonden partijen}

Zoals eerder vermeld noemt IAS 34 een aantal toelichtingen dat, mits materieel, altijd dient te worden opgenomen. Een aantal daarvan is in de voorgaande paragrafen aan de orde gekomen. De hoofdregel blijft echter dat alle gebeurtenissen en transacties met een significante invloed op de prestaties en financiële positie van ondernemingen moeten worden toegelicht. In IAS 34.17 wordt ter illustratie een aantal van dergelijke toelichtingen opgesomd, waaronder transacties met verbonden partijen.

In het AFM-onderzoek hebben 32 (53\%) ondernemingen een toelichting opgenomen over eventuele transacties met verbonden partijen. Daarbij constateert de AFM dat de toelichting op verbonden partijen veelal bestaat uit een verwijzing naar de laatst gepubliceerde volledige jaarrekening. Wij vinden een dergelijke wijze van toelichten passen in de gedachte van IAS 34, dat de tussentijdse verslaggeving zich richt op de relevante wijzigingen ten opzichte van de laatste volledige jaarrekening. De AFM noemt een dergelijke toelichting echter beperkt. Wij kunnen deze opmerking begrijpen vanuit de regels voor het halfjaarverslag, waarvoor de $\mathrm{Wft}$ stelt dat die de belangrijkste transacties met verbonden partijen bevat (Wft 5:25d, lid 9). Gezien het belang van materiële transacties met verbonden partijen voor het inzicht in de prestaties van de onderneming, zijn wij van mening dat deze toelichting ook in de halfjaarrekening dient te worden opgenomen en niet kan worden volstaan met een verwijzing naar de laatst gepubliceerde jaarrekening.

In 44 buitenlandse halfjaarrekeningen $(73 \%)$ wordt melding gemaakt van transacties met verbonden partijen. In 20 van deze halfjaarrekeningen wordt alleen verwezen naar de laatst verschenen jaarrekening (2008) voor de toelichting 
Figuur 4 ABInBev, niet-geauditeerde halfjaarlijkse financiële staten voor de periode van zes maanden eindigend op 30 juni 2009 , p. 39

\begin{tabular}{|c|c|c|c|c|}
\hline \multicolumn{5}{|l|}{ 20. AANVERWANTE PARTIJEN } \\
\hline \multicolumn{5}{|c|}{ TRANSACTIES MET LEDEN VAN DE RAAD VAN BESTUUR EN EXECUTIVE BOARD MANAGEMENT (MANAGERS OP SLEUTELPOSITIES) } \\
\hline \multicolumn{5}{|c|}{$\begin{array}{l}\text { Boven op hun personeelsbeloningen op korte termijn (hoofdzakelijk salarissen) hebben de leden van het "executive board management" van AB InBev ook recht op beloningen na } \\
\text { uitdiensttreding. In het bijzonder nemen ze deel aan het pensioenplan van hun respectievelijk land. "Executive board management"-leden nemen ook deel aan het aandelenoptie- of } \\
\text { omrulprogramma van de groep. De totale vergoeding van de leden van de raad van bestuur en van het "executive board management" opgenomen in de resultatenrekening kan als volgt } \\
\text { samengevat worden: }\end{array}$} \\
\hline \multirow[b]{2}{*}{$\begin{array}{l}\text { Voor de periode van zes maanden eindigend } \\
\text { op } 30 \text { juni Miljoen USD }\end{array}$} & \multicolumn{2}{|r|}{2009} & \multicolumn{2}{|r|}{2008} \\
\hline & $\begin{array}{l}\text { Leden van de raad } \\
\text { van bestuur }\end{array}$ & $\begin{array}{l}\text { Leden van het "executive } \\
\text { board management" }\end{array}$ & $\begin{array}{l}\text { Leden van de raad } \\
\text { van bestuur }\end{array}$ & $\begin{array}{l}\text { Leden van het "executive } \\
\text { board management" }\end{array}$ \\
\hline Personeelsbeloningen (korte termijn)................................. & 2 & 42 & 2 & 23 \\
\hline Beloningen na uitdiensttreding............................................... & - & 1 & - & 2 \\
\hline Voordelen bij het beëindigen van de tewerkstelling........... & - & - & - & - \\
\hline \multirow[t]{2}{*}{ Op aandelen gebaseerde betalingen......................................... } & 1 & 30 & 1 & 13 \\
\hline & 3 & 73 & 3 & 38 \\
\hline \multicolumn{5}{|c|}{$\begin{array}{l}\text { De vergoedingen aan de bestuursleden bestaan vooral uit erelonen (tantièmes). Managers op sleutelposities waren niet betrokken in transacties met AB InBev en hadden geen belangrijke } \\
\text { openstaande vorderingen of schulden met de onderneming, met uitzondering van een consultancyovereenkomst gesloten tussen AB InBev en de heer Busch IV in verband met de fusie } \\
\text { en die loopt tot } 31 \text { december 2013. Krachtens de beoogde bepalingen van de consultancyovereenkomst ontving de heer Busch IV een eenmalig bedrag in contanten van 10,3m USD. Aan } \\
\text { de heer Busch IV zal tijdens de consultancyperiode een vergoeding worden betaald van circa } 120000 \text { USD per maand. Daarnaast wordt een geschikt kantoor in St. Louis, Missouri, ter } \\
\text { beschikking gesteld van de heer Busch IV, evenals administratieve ondersteuning en bepaalde werknemervoordelen die wezenlijk gelijkaardig zijn aan de voordelen die worden verstrekt } \\
\text { aan voltijdse werknemers van Anheuser-Busch. }\end{array}$} \\
\hline
\end{tabular}

en gemeld dat hierin geen materiële wijzigingen hebben plaatsgevonden. $\mathrm{Bij}$ de overige 24 halfjaarrekeningen constateren wij twee verschillende manieren van toelichten. De eerste is dat wordt verwezen naar de jaarrekening 2008 en dat een paar specifieke transacties met verbonden partijen in het eerste halfjaar worden toegelicht. Daarnaast zijn er ondernemingen die niet verwijzen maar een, voor zover voor ons zichtbaar, volledige IAS 24-toelichting opnemen in de halfjaarrekening. Een goed voorbeeld van deze variant is $\mathrm{ABInBev} \mathrm{NV}$, die in deze toelichting ook de beloning van de managers op sleutelposities over de zesmaandsperiode opneemt (zie figuur 4).

Een uitgebreide toelichting op transacties met verbonden partijen wordt verstrekt door Eni Spa (zes pagina's) en bevat mede de effecten van transacties met verbonden partijen op het kasstroomoverzicht (zie figuur 5). De effecten van transacties met verbonden partijen op het kasstroomoverzicht zijn wij nergens anders tegengekomen in de onderzochte halfjaarrekeningen en wordt ook niet expliciet voorgeschreven in IAS 24. Gezien het belang van het kasstroomoverzicht voor investeerders zijn wij van mening dat het toelichten van de effecten van deze transacties op het kasstroomoverzicht het inzicht ten goede komt indien er sprake is van significante transacties met verbonden partijen.

\subsection{Schattingswijzigingen}

IAS 34.16 (d) vraagt om een toelichting op de aard en het bedrag van schattingswijzigingen indien deze wijzigingen een materieel effect hebben op de lopende tussentijdse periode, oftewel het halfjaar waarover gerapporteerd wordt. In de rapportage van de AFM wordt over dit punt niets gemeld. Litjens geeft wel aan dat schattingswijzigingen worden toegelicht, maar gaat hier inhoudelijk verder niet op in. Bij jaarrekeningen zien wij vaak dat de toelichting op schattingen en oordeelsvorming (IAS 1.122 en 125) beperkt blijft tot algemeenheden.

In de onderzochte buitenlandse halfjaarrekeningen hebben wij in $33(55 \%)$ halfjaarrekeningen een toelichting op dit punt aangetroffen. Vaak gaat dit niet verder dan aan te geven dat zich hierin geen materiële wijzigingen hebben voorgedaan en wordt verwezen naar de jaarrekening 2008. Een tweetal voorbeelden waarbij buitenlandse onderne- 
Figuur 5 Eni, Interim Consolidated Report as of June 30, 2009, p. 122

The main cash flows with related parties were as follows:

\begin{tabular}{lc|c}
$(€$ million) & First Half 2008 & First Half 2009 \\
\hline Revenues and other income & 2145 & 1768 \\
\hline Costs and other expenses & $(1619)$ & $(2317)$ \\
\hline Other operating income (loss) & & 35 \\
\hline Net change in trade and other receivable and liabilities & 273 & 109 \\
\hline Dividends and net interests & 307 & 273 \\
\hline Net cash provided from operating activities & 1106 & $(132)$ \\
\hline Capital expenditures in tangible and intangible assets & $(495)$ & $(612)$ \\
\hline Change in accounts payable in relation to investments & 41 & 213 \\
\hline Change in financial receivables & $(372)$ & 125 \\
\hline Net cash used in investing activities & $(\mathbf{8 2 6})$ & $(274)$ \\
\hline Change in financial liabilities & 125 & 2 \\
\hline Net cash used in financing activities & 125 & 2 \\
\hline Total financial flows to related parties & 405 & $(\mathbf{4 0 4 )}$ \\
\hline
\end{tabular}

The impact of cash flows with related parties consisted of the following:

(€ million)

\begin{tabular}{|c|c|c|c|c|c|c|}
\hline & \multicolumn{3}{|c|}{ First Half 2008} & \multicolumn{3}{|c|}{ First Half 2009} \\
\hline & Total & $\begin{array}{l}\text { Related } \\
\text { parties }\end{array}$ & Impact \% & Total & $\begin{array}{l}\text { Related } \\
\text { parties }\end{array}$ & Impact \% \\
\hline Cash provided from operating activities & 9950 & 1106 & 11,12 & 7621 & (132) &.. \\
\hline Cash used in investing activities & (9483) & (826) & 8,71 & $(3781)$ & (274) & 7,25 \\
\hline Cash used in financing activities & (1048) & 125 & .. & (4439) & 2 &. \\
\hline
\end{tabular}

Figuur 6 ABInBev, niet-geauditeerde halfjaarlijkse financiële staten voor de periode van zes maanden eindigend op 30 juni 2009, p. 25

Bij het opstellen van deze verkorte geconsolideerde halfjaarlijkse financiële staten zijn de voornaamste inschattingen van het management bij de toepassing van de waarderingsregels van de groep alsook de belangrijkste bronnen om onzekerheid in te schatten dezelfde als die van toepassing op de geconsolideerde jaarrekening voor het boekjaar eindigend op 31 december 2008, behalve voor de verwerking van een inperking na de wijziging van bepaalde pensioenbeloningen en gezondheidszorgen na opruststelling als onderdeel van de Anheuser-Busch integratie. Het effect van deze veranderingen werd door actuarissen geschat en leidde tot een toename van de bedrijfswinst en van de winst van 240m USD en 147m USD, respectievelijk, voor de zes maanden eindigend op 30 juni 2009. mingen een toelichting opnemen op dit punt, die relevante informatie bevat over aanpassingen in schattingen, is opgenomen in figuur 6 en 7 .

\subsection{Betrokkenheid van de accountant}

De AFM constateert dat met de invoering van de Transparantierichtlijn de betrokkenheid van de accountant is vergroot. Daarbij gaat het steeds om een beperkte beoordeling door de accountant, bij geen enkele Nederlandse onderneming is er sprake van een volledige accountantscontrole. Van de door de AFM onderzochte ondernemingen heeft $28 \%$ de halfjaarrekening door de accountant laten beoordelen. In het voorafgaande jaar was dat nog $17 \%$. De AFM veronderstelt dat de betrokkenheid van een accountant een positieve invloed heeft op de kwaliteit van de halfjaarlijkse financiële verslag- 
Figuur 7 EDF, Group Condensed Consolidated half-year Financial Statements at June 30, 2009, p. 11

\author{
1.4 Management judgment and estimates \\ The preparation of the financial statements requires the use of judgements, best estimates and assumptions in determining the value of assets and liabilities, \\ income and expenses recorded for the period, and positive and negative contingencies at the closing date. The figures in future financial statements may \\ differ from current estimates due to changes in these assumptions or economic conditions. \\ The estimates and assumptions used in establishing the consolidated half-year financial statements at June 302009 are the same as those described in note \\ 2.2 of the consolidated financial statements at December 31, 2008. \\ Against the economic and financial crisis that began in 2008 , mainly characterized by high volatility on the financial markets, the parameters used to prepare \\ estimates are based on macro-economic assumptions appropriate to the very long-term cycle of Group assets. A sustained serious prolongation of this crisis \\ could lead to revision of some of the long-term assumptions used in determining the value of assets and liabilities, and in assessment of positive and negative \\ factors at reporting date. \\ The quantities of energy delivered but neither measured nor billed are calculated at the reporting date based on consumption statistics and selling price \\ estimates. These statistics and estimates are sensitive to the assumptions used in determining the portion of sales not billed at the closing date. \\ The measurement of provisions for the back-end nuclear cycle, decommissioning and last cores in sensitive to assumptions concerning costs, inflation rate, \\ long-term discount rate, and disbursement schedules. A revised estimate is therefore established at each closing date to ensure that the amounts accrued \\ correspond to the best estimate of the costs eventually to be borne by the Group. Any significant differences resulting from these revised estimates could \\ entail changes in the amounts accrued (see note. 26.2). \\ These provisions amount to $€ 37,197$ million at June 30, 2009 (compared to $€ 29,018$ million at December 31, 2008) including €8,000 million for British Energy,
}

geving. Deze veronderstelling is in het onderzoek van Litjens getoetst. De conclusie uit dat onderzoek is dat de kwaliteit van halfjaarrekeningen die door een accountant zijn beoordeeld significant hoger ligt dan die van halfjaarrekeningen die niet zijn beoordeeld. De door de accountant beoordeelde halfjaarrekeningen voldeden gemiddeld aan $92 \%$ van de door Litjens onderzochte criteria, tegen $71 \%$ van de niet-beoordeelde halfjaarrekeningen.

De betrokkenheid van de accountant bij de 60 onderzochte buitenlandse halfjaarrekeningen is beduidend groter dan in Nederland. Bij twee ondernemingen zijn de cijfers gecontroleerd door een accountant en bij 45 heeft de accountant een beoordelingsverklaring afgegeven. Dit betekent dat bij in totaal 47 (78\%) van de buitenlandse halfjaarrekeningen de accountant betrokken is, een significant hoger percentage dan in Nederland. Hoewel geen onderwerp van dit onderzoek is ons bekend dat bijvoorbeeld in Frankrijk de betrokkenheid van de accountant bij de halfjaarrekening is voorgeschreven.

\section{Conclusies}

In het algemeen is de compliance van de onderzochte buitenlandse halfjaarrekeningen beter dan van Nederlandse halfjaarrekeningen. Dit komt bijvoorbeeld tot uiting bij de opname van het nieuwe statement of comprehensive income, segmentatie-informatie, volledigheid van de informatie over bedrijfscombinaties en informatie over verbonden partijen. De belangrijkste verklaring die wij hiervoor hebben, is dat de betrokkenheid van de accountant bij de halfjaarrekening in het buitenland significant groter is dan in Nederland. Deze relatie wordt ook verondersteld door de AFM en komt overeen met de conclusie van het onderzoek van Litjens. Verder bestaat de verplichting tot het opstellen van een halfjaarrekening conform IAS 34 in de meeste Europese landen al langer dan in Nederland, waardoor buitenlandse ondernemingen meer ervaring hebben met het opstellen hiervan. Ook een verklaring zou kunnen zijn dat de onderzochte buitenlandse ondernemingen gemiddeld genomen groter zijn dan de door de AFM onderzochte ondernemingen en zij meer middelen tot hun beschikking hebben. Ten slotte lijkt een positieve invloed uit te gaan van eisen in sommige landen die een bepaalde vorm van rapporteren voorschrijven. Extra voordeel is dat dit bijdraagt aan de leesbaarheid, omdat alle IAS 34-informatie in de halfjaarrekening wordt opgenomen en niet deels in het halfjaarverslag.

Gezien de relatieve late invoer van de verplichting tot het opstellen van een halfjaarrekening conform IAS 34 is het interessant om dit onderzoek over een paar jaar te herhalen als in Nederland meer ervaring is met het opstellen van een IAS 34-halfjaarrekening.

Drs. W.A. Koster RA is als Director verbonden aan het

Department of Professional Practice van KPMG Accountants N.V.

Drs. H.W. Opentij RA is werkzaam als Senior Manager Audit en

tevens verbonden aan Bureau Vaktechniek van BDO

Accountants.

Deze bijdrage is geschreven op persoonlijke titel. 
Noot

1 De Transparantierichtlijn betreft Richtlijn 2004/109/EG. Richtlijn 2007/14/EG bevat

uitvoeringsvoorschriften bij de Transparantierichtlijn.

\section{Literatuur}

aFM (2010), Themaonderzoek 2009 Halfjaarlijkse financiële verslaggeving (halfjaarbericht) door beursgenoteerde ondernemingen; zie: www.afm.nl.

Bonham, M., R. Crisp, M. Curtis, M. Davies, P. Dekker, T. Denton, L. Ellis, M. Lloyd, J. Luke, R. McCracken, R. Moore, R. Overend, H. Richards, T. Rogerson en M. Williams (2010), International GAAP ${ }^{\circledR}$ 2010, John Wiley \& Sons Inc. i.s.m. Ernst \& Young.

Europees Parlement en De Raad (2004), Richtlijn 2004/109/EG van het Europees Parlement en De Raad van 15 december 2004 betreffende de transparantievereisten die gelden voor informatie over uitgevende instellingen waarvan effecten tot de handel op een gereglementeerde markt zijn toegelaten, Publicatieblad van de Europese Unie: Straatsburg; zie eur-lex.europa.eu. Europese Commissie (2007), Richtlijn 2007/17/EG van de Commissie van 8 maart 2007 tot vaststelling van concrete uitvoeringsvoorschriften van een aantal bepalingen van Richtlijn 2004/109/EG betreffende de transparantievereisten die gelden voor informatie over uitgevende instellingen waarvan effecten tot de handel op een gereglementeerde markt zijn toegelaten, Publicatieblad van de Europese Unie: Straatsburg; zie: eur-lex.europa.eu. - EU Commission Staff (2010), EU Commission Staff Working document: The review of the operation of Directive 2004/109/ EC: emerging issues, Annex 3, p. 35-37; zie: ec.europa.eu/internal_market/securities/docs/ transparency/directive/sec-2010_611_en.pdf. - IASB (2009), IAS 34, International Financial Reporting Standards, IASB Foundation; zie: www.iasb.org.

- KPMG (2009), Implementatie van de transparantierichtlijn leidt tot extra waarderingsen toelichtingsvraagstukken. - Litjens, H.J.R. (2010), Onderzoek naar halfjaarrekening Nederlandse beursfondsen: Betrokkenheid accountant verhoogt de kwaliteit!, Accountancynieuws, nr. 9, pp. 16-18. 
Bijlage 1 Onderzochte buitenlandse ondernemingen met aanduiding van land van vestiging

\begin{tabular}{|c|c|c|c|}
\hline A.P. Moller - Maersk & DK & Hennes \& Mauritz & SE \\
\hline AXA & FR & Iberdrola & ES \\
\hline Allianz & DE & Iberdrola Renovables & ES \\
\hline Alstom & FR & Imperial Tobacco Group & GB \\
\hline Anglo American & GB & Inditex & ES \\
\hline ABInBev & $\mathrm{BE}$ & Intesa-Sanpaolo & IT \\
\hline ArcelorMittal & $L U$ & L'Oreal & FR \\
\hline AstraZeneca & $\mathrm{GB}$ & LVMH & FR \\
\hline BAE Systems & GB & Lafarge & FR \\
\hline BASF & DE & Lloyds Banking Group & GB \\
\hline BG Group & GB & Metro & DE \\
\hline BMW Group & DE & Munich Re Group & $\mathrm{DE}$ \\
\hline BNP Paribas & FR & National Grid & GB \\
\hline BP & GB & Nestle & $\mathrm{CH}$ \\
\hline Banco Bilbao Vizcaya Argentaria & ES & Nokia & $\mathrm{Fl}$ \\
\hline Banco Santander & ES & Nordea & SE \\
\hline Barclays Bank & GB & Novartis & $\mathrm{CH}$ \\
\hline Bayer & DE & Novo Nordisk & DK \\
\hline British American Tobacco & GB & RWE & DE \\
\hline Centrica & GB & Reckitt Benkiser & GB \\
\hline Credit Agricole & FR & Roche & SW \\
\hline Daimler & DE & Royal Dutch Shell & GB \\
\hline Danone & FR & SABMiller & GB \\
\hline ENI & IT & SAP & $\mathrm{DE}$ \\
\hline EDF & FR & Sanofi Aventis & FR \\
\hline Ericsson & SE & Schneider Electric & FR \\
\hline Fortum & $\mathrm{Fl}$ & Scotisch \& Southern Energy plc & GB \\
\hline France Telecom & FR & Siemens & $\mathrm{DE}$ \\
\hline GDF SUEZ & FR & Saint-Gobain & FR \\
\hline GlaxoSmithKline & GB & StatoilHydro & NO \\
\hline
\end{tabular}

